\title{
National Drug Code Unit of Measure
}

National Cancer Institute

\section{Source}

National Cancer Institute. National Drug Code Unit of Measure. NCI Thesaurus. Code C155837.

A unit of measure that is required when submitting a national drug code for billing purposes. 